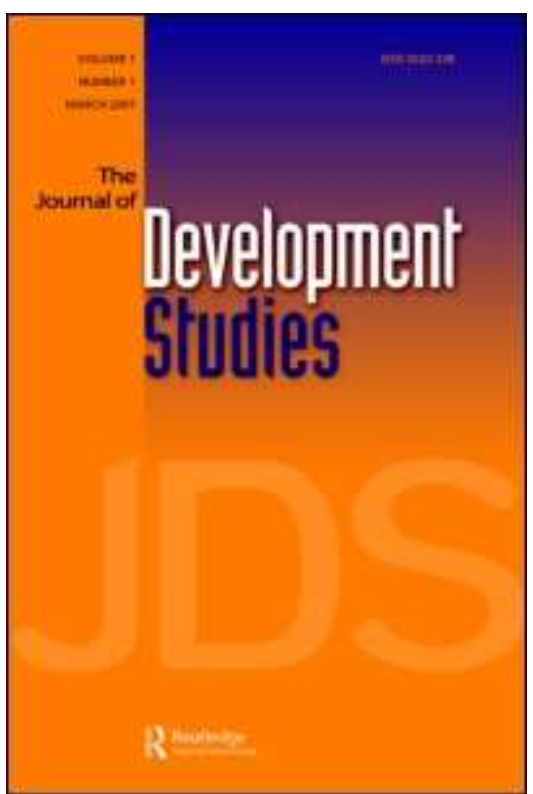

\title{
Are Alternative Livelihood Projects Alleviating Poverty in Mining Communities? Experiences from Ghana
}

\begin{tabular}{|r|l|}
\hline Journal: & Journal of Development Studies \\
\hline Manuscript ID: & FJDS-2007-Feb-0012.R1 \\
\hline Manuscript Type: & Original Manuscripts \\
\hline Keywords: & $\begin{array}{l}\text { Alternative Livelihood (AL) projects, Poverty < Social Issues, Local } \\
\text { Economic Development (LED) projects, mining, Ghana }\end{array}$ \\
\hline \multicolumn{2}{|l}{} \\
\hline
\end{tabular}

\section{s ScholarONE" \\ Manuscript Central}




\title{
Are Alternative Livelihood Projects Alleviating Poverty in Mining Communities? Experiences from Ghana
}

\author{
Gavin Hilson $^{1 *}$ and Sadia Mohammed Banchirigah ${ }^{2}$ \\ ${ }^{1}$ University of Reading, $U K$ \\ ${ }^{2}$ University of Manchester, Manchester, UK
}

Final version received August 2007

\begin{abstract}
This paper critiques the approach being taken in Ghana to implement Alternative Livelihood (AL) projects in mining communities. The rapid insurgence of illegal artisanal gold mining has forced policymakers to think more creatively about ways in which to deal with mounting unemployment in the country's rural areas. Most of the economic activities being promoted, however, have proved highly unpopular with target groups. The policy approaches adopted reflect how little in tune the organizations championing $A L$ activities are with the mindsets and ambitions of rural populations.
\end{abstract}

Keywords: Alternative Livelihood (AL) projects; rural livelihoods; mining; Ghana; poverty

\footnotetext{
* Correspondence Address: Gavin Hilson, School of Agriculture, Policy and Development, The University of Reading, Earley Gate, P.O. Box 237, Reading RG6 6AR, UK Email address: G.M.Hilson@reading.ac.uk
} 


\section{Introduction}

Over the past two decades, more than 90 - mainly developing - countries have redrafted their mineral codes in order to attract outside investment (Bridge 2004). Cash-strapped because of largely misguided mine nationalizations in the 1960s and 1970s (Auty, 1994), many governments have implemented major mining sector reforms, often alongside sustained programs of economic stabilization and structural adjustment. Under reform, mineral policies have been revised to provide a series of financial incentives to help lure previously-wary foreign investors; relevant government agencies have been strengthened; legislation has been redrafted and enacted; and parastatals have been privatized (Morgan 2002). The World Bank alone has provided US\$3 billion in financing for 22 mining sector reform projects in 16 developing countries (World Bank, 2004).

An influx of foreign investment has facilitated unprecedented increases in mineral production throughout sub-Saharan Africa, Asia and Latin America. Primary examples include the marked rise in copper production experienced in Zambia over the past decade; the sharp increases in gold and bauxite mine production witnessed in Ghana since the mid-1980s; and the rapid expansion of gold mining in Peru (Aryee 2001; Bury 2004; Ruffini 2006). The Bank and its private sector partners argue that in addition to providing host governments with export earnings and royalties, a liberalized mining economy dominated by foreign multinationals creates employment opportunities for local people, facilitates technology transfer, catalyzes improvements in physical infrastructure, and leads to the growth of downstream industries (Pegg, 2003).

At the same time, however, and something which is regularly overlooked in macroeconomic appraisals of mining sector reform, operations have had a detrimental impact on rural communities; and, despite claims made by World Bank officials that may suggest otherwise, because they are highly mechanized, mines rarely prove to be employment engines over the long term (after Pegg, 2006). Large-scale mining and mineral exploration activities have displaced hundreds of thousands of rural dwellers in the developing world: the farmlands and rangelands on which they have long subsisted have been demarcated to multinational mining companies. Unable to find employment elsewhere, many of the displaced have taken up employment as illegal artisanal miners, working both near-surface hard rock and alluvial deposits, in many cases, on the very lands awarded to mining companies (ILO 
1999; Andrew 2003). The informal artisanal mining sector has grown rapidly over the past decade, in many cases, chaotically, alongside expanding large-scale mining operations.

Governments traditionally have tackled the illegal mining problem with force, calling upon national security forces to remove encroaching operators from concessions. Periodic government and industry-sponsored "sweeps" of informal mining camps, however, have generally done little to deter industry participation (Hilson et al., 2007a). In fact, these antagonistic approaches have had the opposite effect, unifying groups of people that have been marginalized by the state: artisanal mining camps are becoming increasingly organized, stratified and policed, providing refuge to tens of thousands of men, women and children. It has taken a considerable amount of time for policymakers at the World Bank, United Nations and donor agencies such as the UK Department for International Development (DfID) to finally acknowledge that artisanal and small-scale mining (ASM) ${ }^{1}$ is povertydriven (Barry, 1996; Labonne and Gilman 1999); and, perhaps more importantly, that large-scale mining sector reforms are, at least in part, fuelling the sector's rapid growth (Banchirigah, 2006). The size of the global ASM sector - conservatively estimated by the ILO to be in the range of 13 million (ILO 1999; Andrew 2003) - has forced policymakers to reconsider their approaches to dealing with illegal operators, the majority now accepting that cooperation, not confrontation, is the best way forward.

The growing consensus in policymaking circles is that incidences of illegal mining can be reduced if alternative employment is made available. Many governments, donor bodies and mining companies have therefore implemented a series of Alternative Livelihood (AL) projects in an ambitious attempt to diversify the economies of rural communities dependent upon illegal artisanal mining for sustenance. Officials argue that the - mainly-agrarian - activities being promoted and skills training provided under these schemes put people in an improved position to earn consistent incomes. They further maintain that these activities will, in the end, discourage people from taking up employment in artisanal mining which, in addition to being comprised of predominantly illegal operators, is also associated with environmental degradation and numerous social ills, such as HIV/AIDS and prostitution (UN 1996; Hinton et al. 2003). On the one hand, the moves taken to develop the economies of rural communities signify that stakeholders at the institutional level believe that incomeearning activities must be made available if displaced populations are to be discouraged from 
participating in illegal activities, foremost artisanal mining. On the other hand, little is known about whether the AL projects implemented to date are slowing the growth of informal mining, if at all.

Focusing upon the Ghana experience, this article critically assesses how effective attempts to diversify the economies of mining communities have proved in practice. Ghana featured as a main country case in the inaugural mining-livelihoods exercises launched by the Department of Economic and Social Affairs (DESA) of the United Nations and DfID; and, perhaps more so than any other developing country, its principal large-scale mine operators have heavily embraced "livelihoods" policy, each having implemented a comprehensive AL program that targets specific rural communities. The paper draws upon feedback from interviews with mining company officials and government officers in Accra, and empirical findings gathered in three of Ghana's major mining regions: the Tarkwa-Bogoso-Prestea axis (Western Region), Noyem/Ntronang (Eastern Region), and Bolgatanga (Upper East Region).

\section{Mining and Livelihoods}

The concept of "livelihoods" surfaced in the international development literature in the early1990s, largely in response to the publication of Chambers and Conway's seminal report, Sustainable Rural Livelihoods: Practical Concepts for the $21^{\text {st }}$ Century (Chambers and Conway, 1991). The authors are credited with introducing the term "sustainable livelihoods" (SL), a phrase which, despite giving rise to a burgeoning literature, remains highly contested.

The confusion surrounding the precise definition and application of SL stems from the multitude of interpretations and assessments put forward by a host of scholars and practitioners in response to Chambers and Conway's call "to provoke discussion by exploring and elaborating the concept" (Chambers and Conway 1991, p. i). Initially, SL was advocated as a "people-centred" development approach, emerging in response to "the changing conception of governance that had its source in global and national processes, [in addition to] changes as to how best to understand rural development from a local perspective" (Havnevik et al., 2006, p. 16). Twymant and Slater (2005, p. 2) attribute its emergence to "...a shift in the development agenda towards more holistic views of the activities and capital assets that households draw on to make a living". It emphasizes "capabilities, equity and sustainability" (Chambers and Conway 1991, p. 5), and is "based upon evolving thinking 
about poverty reduction, the way the poor live their lives, and the importance of structural and institutional issues" (Ashley and Carney 1999, p. 4). Any approach that fosters SL, it is argued, could prove effective in understanding poverty in developing countries, "potentially alter[ing] how development interventions are designed, implemented and evaluated" (Toner, 2003, p. 774).

Recognizing that poverty is dynamic and has many dimensions, DfID - an organization that has played a heavy hand in popularizing the livelihoods concept - developed a SL Framework, "a typology of assets which poor individuals, households and communities deploy to maintain well-being under changing conditions" (Norton and Foster, 2001, p. 12). The organization defines a livelihood as “...the capabilities, assets (including both material and social resources) and activities required for a means of living... [and sees it as] sustainable when it can cope with and recover from stress and shocks and maintain or enhance its capabilities and assets both now and in the future, while not undermining the natural resource base" (Carney, 1998, p. 4). ${ }^{2}$ Throughout rural regions of the developing world, peoples' livelihoods are structured around an assortment of agrarian activities and complementary subsistence occupations: ensuring that these livelihoods are sustainable, as well as protecting and improving the management of the environment, argue officers at DfID, are keys to eradicating poverty. Several other organizations, including CARE and OXFAM, have followed DfID's lead, developing their own SL frameworks in an attempt to establish a connection between local realities and the level "at which policies intended to change these realities are formulated" (Shankland 1998, p. 4).

In the case of mining, SL is used almost exclusively as a developmental objective: it is used interchangeably with "Alternative Livelihoods" (Labonne and Gilman, 1999), the end goal being the economic diversification of rural communities, many of which are impoverished and over-reliant upon illegal artisanal mining for sustenance. Interest in the livelihoods of informal miners and their hardships emerged following the World Bank-hosted International Roundtable on Informal Mining, 1995. Conference delegates reached a consensus that ASM is poverty-driven, attracting individuals with few, if any, alternative income-earning opportunities (Barry, 1996), the conviction being that the sector provides rapid re-entry into the labour market in the absence of significant formal sector employment. As explained in a recent report published by the United Nations Economic Commission for Africa, "increasing numbers of people have turned to small-scale mining to seek alternative livelihoods..., in many cases...impelled by growing economic crises, [and] the effects of structural adjustment, particularly in sub-Saharan Africa, which increased unemployment" (UNECA, 2003, p. 2). 
Banchirigah (2006) reinforces this claim, arguing that throughout sub-Saharan Africa, ASM has proved to be an indispensable source of income for those made redundant under reform, providing scores of people from the public sector and large-scale mining industry with jobs. This has indeed been the case in Tanzania, for example, where Dreschler (2001, p. 64) reports that ASM "resettles those who have lost their jobs in the cities due to the newly adopted structural adjustment programmes". Similarly, in neighbouring Mozambique, "the introduction of the Economic Structural Adjustment Program (ESAP) in 1986 [also] led to a mass displacement of workers...[which] along with an extended period of drought between 1990 and 1993, prompted many retrenched workers and peasants to pan gold in certain provinces" (Mondlane and Shoko, 2003, p. 267).

Recognition that ASM is indeed expanding because of rising unemployment in formal sector channels has led many donors, governments and private sector partners to begin investigating ways in which to further develop and diversify the economies of rural communities. In May 1999, at the Tripartite Meeting on Social and Labour Issues in Small-scale Mines at ILO headquarters in Geneva, the United Nations unveiled plans to launch the first comprehensive mining-SL project, an effort organized by DESA with inputs from staff at the UNDP. As explained by its coordinators:

"Alternative or complementary livelihood activities need to be developed in parallel with artisanal mining...In the typical mining areas there are large numbers of mainly unskilled miners and a limited or unknown quantity of mineable mineral resources; it will therefore be necessary to generate alternative livelihood opportunities so that those remaining in artisanal mining can achieve a reasonable standard of living..." [Labonne and Gilman, 1999, p. 4]

Focusing on Africa, the following countries were selected for the study: Ghana, Mali, Ethiopia and Guinea. Findings were disseminated at the forum, ASM in Africa: Identifying best Practices and Building the Sustainable Livelihoods of the Communities, held in Yaoundé, Cameroon, 19-22 November 2002, where it was claimed by delegates that the initiative has helped to improve understanding of poverty in artisanal mining communities, and has informed policy (Carnegie, 2002). In 2003, DfID launched a second livelihoods project, sponsoring research and technical work in Tanzania and Ghana. The purpose of the project, which is currently in the second of two phases, is to collect baseline livelihoods information on ASM and to provide support to artisanal mine operators.

For any AL program to be effective, the series of "alternative" income-earning activities being promoted should be capable of preventing people from pursuing employment in ASM as well as attracting those already engaged in mining activities. The latter task promises to be the most challenging because contrary to the views of officers at donor agencies and government officials, who 


\section{The Ghana Experience}

As noted at the outset of this paper, Ghana is one country where several mining-AL projects have been launched in recent years. In addition to featuring as a country case in the seminal DESA/UNDP and DfID initiatives, the Ghanaian Government, as well as a number of the country's large-scale mine operators, have implemented an array of AL projects.

An ad hoc policy approach to formalizing activities has exacerbated the illegal mining problem in the country. Indeed, there is a long history of support for ASM in the country, initiated by the World Bank in the early-1990s, with contributions from GTZ and UNIDO. World Bank monies were used, inter alia, to establish a legislative framework for small-scale mining, identify areas suitable for activities, educate operators, and launch equipment leasing schemes. The actions taken under the auspices of the Bank both to regularize and support small-scale mining in Ghana led the United Nations to prematurely describe the country as "a leader in the promotion of small-scale mining enterprises" (UN, 1996, np). However, the millions of dollars pledged to formalize ASM under such projects as the World Bank Ghana Mining Sector Development and Environment Project and EU's Ghana Mining Sector Support Program have targeted legal operators, who constitute a small fraction of the sector's participants. At the same time, little, if any, effort has been made to engage with and support marginalized illegal operators.

Moreover, although organizations such as the World Bank have provided millions of dollars in support for mining in sub-Saharan Africa, the formalization of ASM has been very much an 
afterthought in most development projects. In Ghana itself, emphasis was placed from the beginning on reforming mining laws for large-scale mining, which led to the drafting of a mineral policy that provides a host of investment incentives (Campbell, 2003). To secure the requisite levels of foreign investment in large-scale mining projects, particularly those emphasizing the extraction of gold, the Ghanaian government, under the guidance of the World Bank, modified some 78 acts, ordinances, decrees, codes and laws regulating the sector (Hilson, 2004). These changes led to the drafting and passing of the Minerals and Mining Law (PNDCL 153) in 1986.

The Ghana Minerals Commission, established under Article 269 of the 1992 Constitution and the Minerals Commission Act, provides inputs on national mining issues, monitors activities, and assists with the drafting of policies and regulations. The Minerals and Mining Act of 2006 transformed the Mines Department, first established in 1902, into the Inspectorate Division of the Minerals Commission, and empowered it to enforce laws, regulations and standards. The Commission functions under the direction of The Minister for Lands, Forestry and Mines, who makes the final decisions on reconnaissance, exploration (prospecting) and mining licenses. Changes in legislation have facilitated an increased foreign presence in Ghana's large-scale mining sector and with it, marked increases in mineral production. Today, there are 237 companies exploring for gold alone and another 23 companies are in possession of mining leases (Aryee 2001). According to statistics published by Ghana Chamber of Mines, the representative body of the country's large-scale mining sector, 31,237 $\mathrm{km}^{2}$ or 13.1 percent of the country's land is currently under concession to mining (Ghana Chamber of Mines, 2006).

A somewhat unanticipated impact of the rapid influx of mineral exploration and mining companies into the country, however, has been widespread loss of land and pronounced community displacement in rural areas. As Akabzaa and Darimani (2001, p. 45-46) explain, "[in Ghana,] the [large-scale] mining industry has withdrawn a significant percentage of the labour force from agriculture and other income-generating activities by taking farmland away... [at the same time, failing to] provide enough jobs to match the number of people laid off from agriculture". In addition to highly mechanized large-scale mining operations creating few employment opportunities, "Ghana's very high unemployment rate, particularly for the 15-24 age group (30 percent), coupled with extreme poverty (US\$434 GDP per capita), means that farmers and small-scale miners who lose their land to mining companies have very few means for survival in the formal economy" (Carson et al. 2005, p. 4). 
Officers at Oxfam claim that the Ghanaian government has made available 70 percent of the country's land to large-scale miners (Oxfam, 2005); one third of the Western Region, the location of 50 percent of the country's large-scale gold mines, has been demarcated to mining and mineral exploration companies (Aubynn, 1997).

The Ghanaian Government has collected over US\$68.6 million in royalty payments from mining companies since 1990 (Bank of Ghana, 2003) but few funds have been used to develop rural economies. ${ }^{3}$ Failure to reinvest mine royalties and generate employment in rural communities has forced many Ghanaians to pursue employment in illegal artisanal mining camps. An estimated 200,000 people are currently employed in ASM nationwide (Hilson and Potter, 2005), although when all dependents ${ }^{4}$ are included, the sector provides a livelihood to as many as one million people. The activities of artisanal mine operators - referred to locally as galamsey - are today the backbone of Ghana's subsistence rural economy. The sector has become an unrivalled employment engine, providing hundreds of thousands of jobs to otherwise-unemployed farmers, youths and nomads. ${ }^{5}$ A lack of foresight on the part of the government and mining companies has contributed further to the industry's growth: in the past, minimal emphasis was placed on ensuring that peoples' livelihoods, including their jobs, were restored. The expectation was that compensation would suffice - that the displaced would relocate and find alternative employment on their own.

The government and mining companies are now acting to correct these mistakes, implementing projects which officers claim offer training and direct incomes to needy rural inhabitants. Most are convinced that these AL activities will help discourage further industry participation; there is even some optimism that they will lure many people already engaged in galamsey work. The emphasis hitherto has been to promote the expansion of agrarian activities: oil palm cultivation, cassava farming, poultry, and grass-cutter ${ }^{6}$ and snail rearing. The Minerals Commission and each of the country's major active gold mining companies have implemented AL projects (Figure 1), targeting what they have determined to be "affected communities". These efforts have drawn considerable praise from officers at the Ghana Chamber of Mines, as well as several donor agencies and multilateral organizations.

This paper examines how effective AL projects have proved in practice, drawing upon findings from research undertaken in Tarkwa-Bogoso-Prestea (May-September 2005, July-September 2006), Noyem/Ntronang (January 2006, June 2006) and Bolgatanga (January-February 2006). Each study location is qualitatively unique and, for very different reasons, has a vibrant - predominantly 
illegal - artisanal mining sector. The former (Tarkwa-Bogoso-Prestea) has a long history of large-scale mining; under reform, operations have expanded rapidly, in the process taking land out of the hands of thousands of peasant farmers. Tarkwa, Bogoso and Prestea are all located in the Wassa West District of the Western Region, 60 percent of which is currently under concession to mining and mineral exploration companies (after Aubynn, 1997). ${ }^{7}$ An estimated 40 percent of the district's 250,000 people are currently engaged in subsistence agriculture ${ }^{8}$ it is the location of 44 percent of the country's closed forest; produces 39 percent of the nation's cocoa; and accounts for 50 percent of national timber production (Akabzaa and Darimani, 2001). The district also has one of the highest proportions (57.6 percent) of people in the working age group (15-64) and lowest illiteracy rates (37.4 percent) in the Western Region, which makes identification of "innovative" alternative income-earning activities imperative.

The Eastern Region of Ghana, on the other hand, does not have a rich mining tradition. An estimated 75 percent of the population of Birim North, the district where Ntronang and Noyem are located, depend directly on farming for their livelihoods, ${ }^{9}$ producing plantain, cocoyam, maize, cassava, cocoa, oil palm and citrus fruits (after Dei, 1994). The recent arrival of Newmont Gold Mining to New Abirem, however, has altered community dynamics significantly. The company not only holds an exploration license at New Abirem but also holds prospecting licenses at neighbouring Ntronang and Noyem, where tens of thousands of illegal artisanal miners are currently extracting nearsurface gold deposits. Birim North is one of the most impoverished districts in Ghana, and although there is significant potential to develop agriculture in the region, the majority of its rural people, who comprise more than 70 percent of its population, have limited access to financial support and extension. ${ }^{10}$ In addition to rapid population growth diminishing prospects for farming, it is expected that "with the introduction of large scale mining activities in the district,...land available for agriculture will continue to diminish". The government, therefore, has called for the "district assembly with the new mining companies [to] introduce alternative livelihoods to the people in the district". ${ }^{11}$

The final study location, Bolgatanga, is the capital of the Upper East Region. During the 1990s, it experienced the largest absolute increase in both poverty and extreme poverty in the country (Canagarajah and Portner, 2003). Since areas around Bolgatanga are located within the Sudan Savannah Zone, the region is thus extremely arid: it has a single rainy season characterized by inconsistent rainfall which lasts for up to seven months, poor soils and highly variable microclimates 
(Whitehead, 2004). Close to 90 percent of the Upper East Region is poor, and 80 percent is extremely poor (Canagarajah and Portner, 2003). Moreover, the educational facilities in Bolgatanga and surrounding municipalities are deteriorated, no doubt contributing to the locality's 30 percent school dropout rate. ${ }^{12}$ Many of the unemployed, including numerous youths, have thus sought work in the adjacent Talensi-Nabdam District (Tongo), where there are several alluvial gold deposits ideal for small scale extraction. To encourage legal small-scale mining activity, the Minerals Commission has set aside a $72 \mathrm{~km}^{2}$ plot in Tongo for prospective operators to work, but it appears to have done little to discourage illegal artisanal mining in the Upper East Region overall.

The aim of the research was to survey the views of key stakeholder parties ${ }^{13}$ in order to help answer the following questions:

- How are decisions concerning mining-AL projects arrived at?

- What are the views of mining communities on these projects?

- How effective have these projects been in practice, and to what extent have they addressed Ghana's illegal mining problem?

The wide range of opinions surveyed has helped to shed light on the approach being taken to diversify many of the country's rural economies that rely on illegal mining for sustenance. 
Figure 1: Locations of mining-AL projects implemented in Ghana

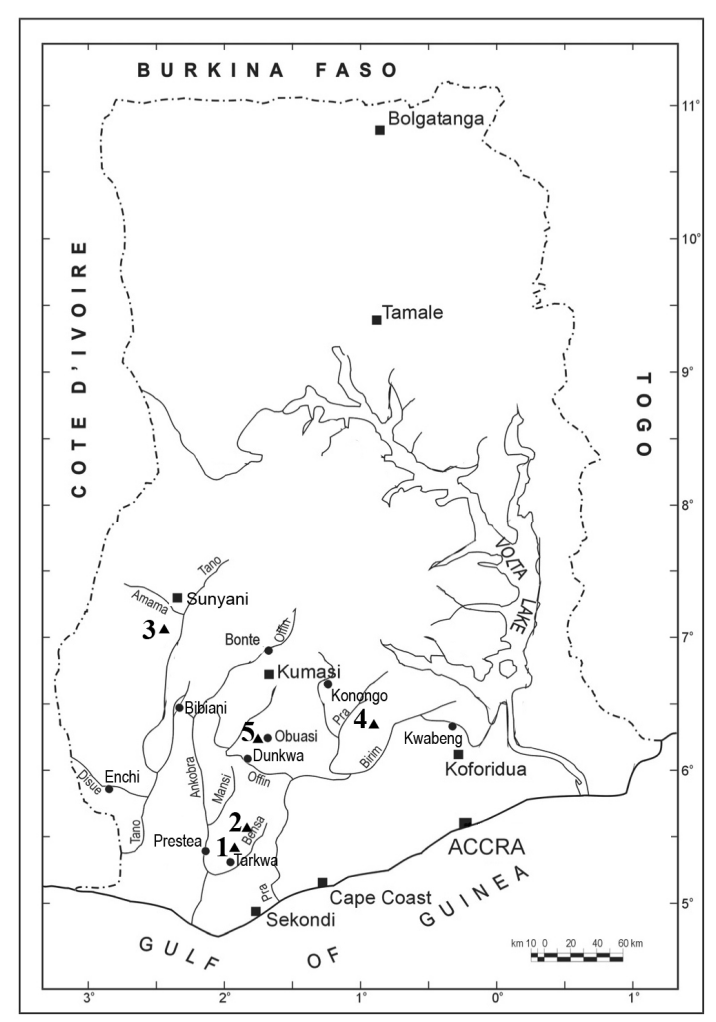

1. Tarkwa-Prestea-Bogoso: Location of BGL's Sustainable Alternative Livelihood Project (poultry, grass-cutter, sericulture and tilapia) and the Minerals Commission's oil palm project.

2. Damang: Gold Fields' Damang mine, where several alternatives, including snail farming and oil palm, are being promoted. 3. Kenyasi: Newmont's Kenyasi mine, where livestock-based livelihoods are being promoted and skills such as soap-making and batik are being provided.

4. New Abirem: Newmont's Akyem mine, which has adopted a "Livelihoods Restoration" program.

5. Obuasi: AngloGold Ashanti's Obuasi mine, where snail farming, as well as poultry and grass-cutter rearing, are being developed.

\section{A Critical Assessment of Ghana's Mining-Livelihood Projects}

Sievanen et al. (2005), who examine seaweed farming as an alternative to artisanal fishing in the Philippines and Indonesia, provide a framework for analyzing the AL projects being implemented in Ghana's mining communities. The authors argue that the promotion of alternative livelihoods is based on the following assumptions: that small-scale fishermen are poor and therefore need to overexploit in order to earn acceptable incomes; that fishermen are willing to abandon farming in favour of other economic opportunities; and that fishers' engagement in alternative livelihoods will reduce pressure on fisheries. Similar assumptions have also been made by the Ghanaian government and major mining companies: that the wealth of alternatives promoted are more attractive than galamsey activity; that individuals are willing to take up these activities; and that the programs being 
implemented are wide-reaching, capable of alleviating significant poverty. Further analysis, however, reveals that neither of these assumptions is correct.

\section{Appropriateness of Projects}

For there to be any chance of discouraging illegal mining in Ghana, the alternatives being developed must be enticing. This is a concern of Professor Dominic Fobih, the Minister of Lands, Forestry and Mines, who at a recent mining seminar in Kumasi (2 August 2006), explained:

"We are introducing the same thing, whether it's grass-cutter, snail, this, that, mushroom...We need a more comprehensive approach [to AL]...In line with the repetitive process we just spoke of, it's time for the mining companies to come up with new projects like skills and value addition...So if we continue to have this grass-cutter project and for...some other thing, it fails, they [the community] will not look at the school you built, or the clinic..."

The implication is that few of the alternative income-earning activities being promoted are innovative, and provide minimal added value to impoverished rural communities. Programs have generally sought to develop subsistence livestock herding and vegetable farming, which assumes - incorrectly - that all targeted groups endeavour to rear grass-cutter or farm cassava.

This raises a more important question: namely, how are decisions concerning which livelihood projects are to be implemented arrived at? In defence of Ghana's mining companies, which are often criticized for taking a cavalier stance toward community participation, most have solicited the services of Philadelphia-headquartered Opportunities Industrialization Centers International (OICI), an international NGO that specializes in rural development, to assist with implementing AL projects. In the words of one mining company official, the need to consult outside experts who have a greater familiarity with Ghanaian culture is imperative because too often, "the company thinks it knows everything, and tends to engineer things, looking at the outcome, rather than the process". On the one hand, the move made by Gold Fields, AngloGold Ashanti and Newmont to contract livelihoods work out to $\mathrm{OICI}^{14}$ signifies that senior mining personnel in Ghana recognize that their predominantly expatriate workforces lack the experience and skill to make important decisions on AL programs - that the services of specialist groups are needed if appropriate income-earning activities are to be identified. On the other hand, the decision of OICI to continue promoting almost exclusively agrarian activities as alternatives raises further questions concerning the degree of autonomy it has been given to make decisions in this area. ${ }^{15}$ 
Communications with a senior officer from one mining operation located in the Tarkwa area suggest that companies may, in fact, be "regulating" the process more so than it appears. The decision of the officer's company to promote oil palm, snails and fish farming as alternatives, it was explained, was "[because] we felt these activities do not take much land". The government also appears to be leaning toward implementing its own livelihoods agenda. Although the Minerals Commission's World Bank-funded AL study - based on work undertaken by an independent consultant, who visited 61 villages in the Western region - concluded that youths were more interested in acquiring skills in the areas of masonry and carpentry than farming (Nyame, 2002), the government has, against these findings, elected to implement an oil palm agricultural project in Prestea, an artisanal mining locality whose economy is in dire need of diversification. Reacting to the news, one local galamsey leader explained during an interview that "[the area] was a farming town, and now it's a mining town...[and that] I don't think there is a serious farmer in [the region] now".

In other cases, policymakers and company officials have clearly implemented their own ideas. Perhaps nowhere has this been more evident than with Bogoso Gold Limited (BGL), a company that is 90 percent owned by Colorado-based Golden Star Resources Ltd. and which controls the Bogoso and adjacent Prestea concessions in the Western Region of the country. Through the Food and Agricultural Organization, the United Nations pledged US $\$ 400,000$ to develop sericulture in Ghana, an activity which has since become the foundation of BGL's Sustainable Alternative Livelihood Project, coordinated from the Beposo Demonstration farm near its Bogoso mine. The company grows mulberry feed and has harvested 80,000 silkworm eggs as part of a program the manager of the project claimed will "assist neighbouring communities to become self-reliant and create employment opportunities for their people". ${ }^{16}$ Yet, Ghana is not a net exporter (producer) of silk; nor is it a major consumer.

At the same time, companies appear to be shying away from implementing the very projects favoured by communities:

"[The people] prefer to engage to become artisanals: fitters, mechanics, technicians. Mine companies need these guys...Instead of giving them poultry and grass-cutters, they prefer they are trained to become artisanals, so companies can use their services, so when the mine is gone, you have a skills pool". [NGO officer]

Whilst there is little denying that agrarian-based project work - described by one mining company officer as "stuff that requires minimal inputs to kick-start" - creates a maximum number of jobs over the short term, such an approach assumes that the skills, education levels and most importantly, the 
ambitions, of target populations are homogeneous. There also appears to be an assumption that a program which proves effective in one locality will be equally effective in another. For example, in Bolgatanga, there is considerable potential for poultry and guinea-fowl rearing activities: with an extreme climate and a short growing season, people would welcome the expansion of local livestock industries, which have been the economic lifeblood of the locality for centuries. In Tarkwa, on the other hand, where there is a richer mining tradition, a higher percentage of educated youths, and greater access to the country's chief economic centres of Accra and Kumasi, it is unlikely that an AL program based exclusively upon livestock rearing would function as effectively. The characteristics of local must be carefully studied when identifying alternatives.

The most dynamic mining-AL initiative implemented to date in Ghana is Newmont's "Livelihood Restoration Program". The program, which targets every household, tenant farmer and landowner whose lands will be used by the company, attempts to restore the livelihoods of affected people; but there remains concern over whether people wish to continue living as they were. Does restoration of one's lifestyle, in many cases in a different area altogether, necessarily mean improvement? For many communities, a mine signifies a new beginning, promising to create opportunities that did not exist before: many of the "recent cases of conflicts between mining companies and communities...indicate the frustrations and expectations of these communities of the role that mining should play in the development of local economies" (MIME Consult, 2002, p. 8). The expectation is for a mining company to not only hire locally to fill the few jobs that its mechanized operations create, but to also use its vast resources to develop comprehensive income-earning programs for catchment communities. Newmont officers are aware of this, and are experimenting with more dynamic alternatives, including an assortment of business ventures and communication centres.

The designers of most mining-AL program in Ghana have overlooked two important issues. The first is earning potential: do the activities being promoted offer the equivalent or preferably, greater, incomes than those offered at galamsey camps? This is unlikely to be the case - that when “compared to small-scale mining, alternative livelihoods such as farming often have lower and less immediate returns" (Carson et. al, 2005, p. 41). Second, do programs offer a multitude of opportunities reflective of the diverse tastes and skill levels of target populations? As Figure 2 illustrates, galamsey camps are major employment engines, providing a wide-range of jobs: general labour, driving positions, and even skilled posts such as book-keeping and accounting. Despite perhaps creating a 
significant number of jobs, a static livelihoods program based upon activities such as poultry rearing and cassava farming is unlikely to dissuade people from seeking employment at galamsey camps, where there are numerous options. Mining-AL programs must therefore be equally dynamic, offering a range of income-earning activities.

Figure 2: The galamsey "employment engine"

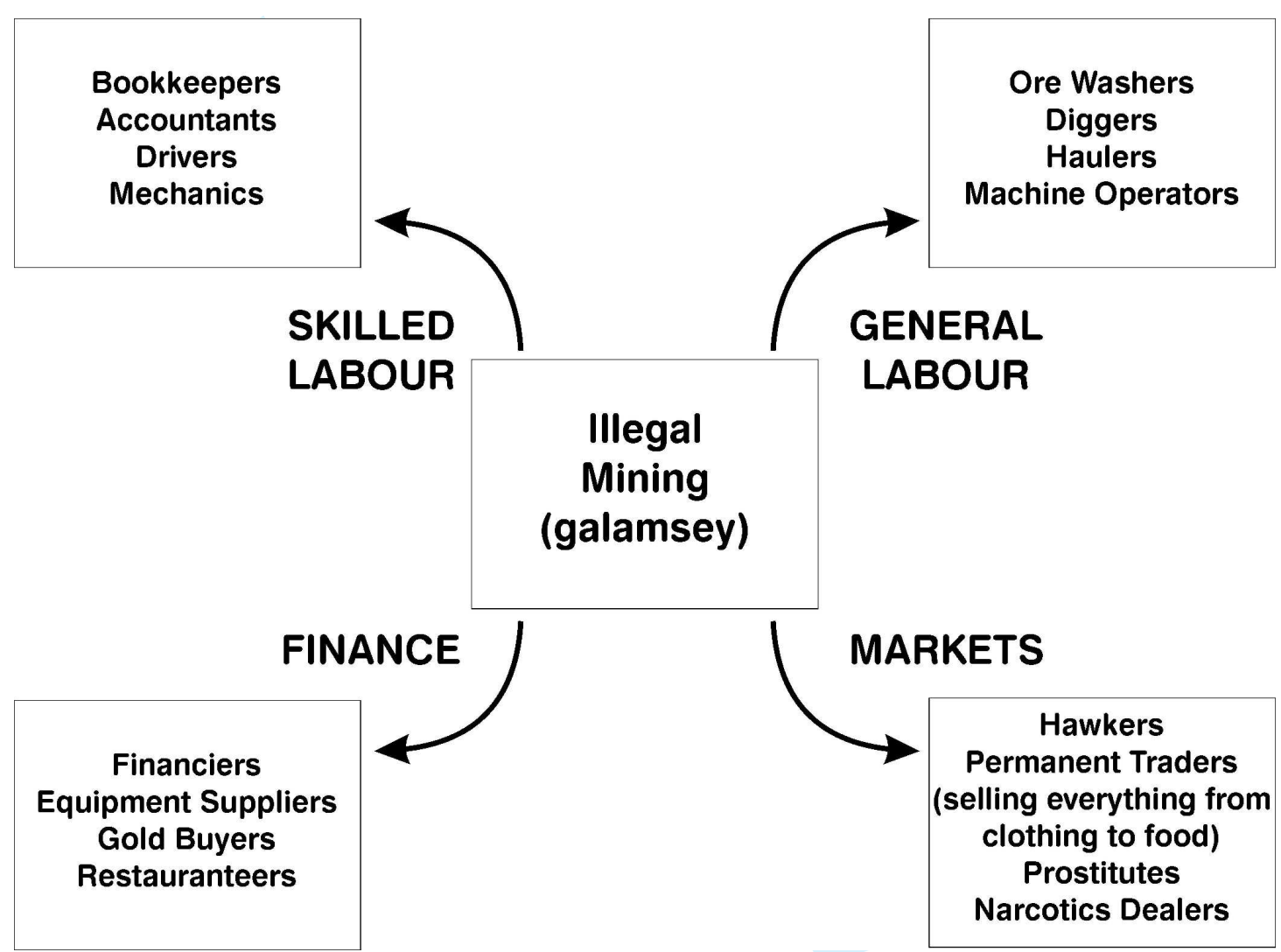

Target Groups

Despite being implemented to discourage illegal mining, few mining companies target galamsey in their AL activities. The programs instituted by OICI, despite appearing comprehensive, target solely those semi-permanent communities located within the catchment areas of large-scale mines (OICI, 2006). In fact, the closest any mining company has gone to engaging directly with galamsey is Gold Fields, which exercises a "live and let live" policy with illegal artisanal miners operating on its concession at Damang (Aubynn, 2006). When queried about why galamsey do not feature in corporate AL programs, one mine manager explained that: 
“...I struggle to see how offering alternative livelihoods is a solution to the galamsey [problem] because you provide jobs for 5000 galamsey and another 5000 will come in to do the same thing".

Whilst it is unrealistic to assume that everyone will abandon artisanal mining if provided alternatives, many of the more vulnerable individuals, including women and the elderly, would if appropriate options were made available. As one galamsey leader in Ntronang explained, pointing at a pregnant woman, "isn't it pathetic to see that woman carry that pan for about 10 times just for a few thousand cedis...If only we had an alternative".

The deliberate exclusion of galamsey is owed largely to a lack of understanding of rural community dynamics in Ghana, which is heavily misguiding mining-AL policy overall. If the goal is to prevent additional illegal mining activity, can a line be drawn between so-called "catchment" settlements, which are believed to be agricultural-based, and galamsey communities (i.e., are they mutually exclusive)? Specifically, is it realistic to assume that the individuals being targeted in AL programs have no association with artisanal mining altogether? There is a burgeoning literature that examines the issue of "livelihoods diversification" in rural environments (see Ellis 1998; Ellis 2000; Bryceson 2002a). Seasonality, credit market imperfections, risk strategies and coping behaviour are frequently identified as reasons why subsistence groups pursue an array of income-earning opportunities. Several empirical studies (e.g. Barrett et al. 2001; Bryceson 2002a; McCusker and Carr 2006) confirm that because of these shocks and other challenges, in sub-Saharan Africa, "nonagricultural income diversification has been substituted in the search for much-needed cash earnings" (Bryceson, 2002b, p. 727). In fact, it is safe to say that today, "very few [of the region's] people collect all their income from any one source, hold all their wealth in the form of any single asset, or use their assets in just one activity" (Barrett et al., 2001, p. 315).

A main reason why individuals engage in ASM is because of the seasonality of agriculture, or, more specifically, the inability of farming to sustain livelihoods throughout the year (after Hentchel et al., 2002). Maconachie and Binn's (2007) longitudinal analysis of diamond mining in Sierra Leone and Chachage's (1995) review of ASM in Tanzania are two of many studies which provide evidence in support of this claim. There are reports of such "de-agrarianization" in Ghana itself (McCusker and Carr 2006; Yaro 2006), including in many of the rural regions where ASM takes place. It would therefore be premature to assume that the groups of farmers being targeted in AL programs are not also engaged in illegal mining - or that farming alone is capable of providing rural Ghanaians with 
By intentionally omitting illegal miners from these exercises, government and miningcompany officials are undermining the very purpose of AL "thinking", which is to facilitate local economic development for impoverished rural populations. The reality is that few of the officers interviewed empathise with the illegal mining cause; and, despite emerging evidence that may suggest otherwise (Hilson and Maponga 2004; Hilson and Potter 2005), most insist that catchment farming communities and galamsey populations are distinctly different, and have minimal association with one another. One officer at the Ghana Chamber of Mines went to such lengths to declare that "illegal mining [in Ghana] is not believed to be a poverty-driven activity", implying that there are employment options in rural regions of the country. If such a mindset is representative of Ghana's policymakers, most AL initiatives have little chance of succeeding: if projects are being conceived to discourage additional illegal activities as claimed, then allowing existing galamsey operations to flourish would be counterproductive. If ASM camps are within range, the individuals being "re-skilled" will always have the option to participate in what they may perceive, in time, to be a "successful" venture, especially if their "new" profession - likely some agrarian activity - provides comparatively fewer returns. Regular interactions with miners and repeated talks of "getting rich quick" would surely tempt people to join burgeoning galamsey groups.

In Ghana, the policy response to the AL challenge has been poor overall, beginning with the inaugural mining-livelihoods project launched by DESA:

"The contract for the assignment delayed due to communication problems and was finally signed in April 2002. [We] commenced the assignment in late April, and the field survey was undertaken in three mining communities between late April and May 2002...Due to resource limitation and time constraints information was not collected by moving to individual 
households, instead three groups numbering between 15-25 each were selected in each community for the focus group discussion at convenient locations within the communities within a specific time block". [MIME Consult, 2002, p. 4, 6]

As for more recent initiatives, government and company officials, despite expressing concerns about the growing illegal artisanal mining problem, have shown little urgency with implementing projects. For example, despite undertaking the necessary baseline research in 2000, the Minerals Commission has yet to implement its oil palm project in Prestea because “...some 9.2 billion cedis [has yet] to be released". During the six years that have passed since undertaking the baseline research, however, the communities targeted - Himan, Nsuta-Mbeasi, Huni-Valley, and Awodua - have grown increasingly dependent upon artisanal mining for sustenance, an attachment that could prove difficult to sever. For BGL's "fish pond", it has been more of a case of poor planning. The original pond, constructed in 2004, was not graded properly and contained too many rocks, which made it difficult to harvest tilapia. Although the new pond, in the words of the manager, "is fine", fish have only recently been introduced, some two years after the inception of the company's Sustainable Alternative Livelihood Project; nor has the company set a price for its tilapia. Officers at BGL seem unmotivated to address the mounting illegal mining problem in Prestea, taking exorbitant amounts of time to implement the company's tilapia program and other AL projects. ${ }^{17}$

Moreover as Carson et al. (2005, p. 4) explain, "re-skilling programmes undertaken so far have had only limited impact, mainly due to lack of financing available for participants to start new business ventures". Government and company officers continue to overlook ASM's intimate association with poverty, and what implications this has for rural inhabitants - the importance, as one company official put it, of "prov[ing] that moving them (to other jobs) will get them at least what they are getting as galamsey". People pursue employment at artisanal mining sites in the first place because earnings are immediate, consistent and generally, higher than comparative agricultural employment. Officers at the Minerals Commission, however, are asking the 1000 families it is targeting in the first phase of its oil palm project to continue being poor, proposing to provide them with an annual income of US\$236 for their first year of work, a sum that they promise will increase incrementally from yearto-year. ${ }^{18}$ As one galamsey leader explained, "if for oil palm, it takes four years to get income, why would they leave [galamsey]?"

Another issue is the overall size of many AL programs. For example, under BGL's Sustainable Alternative Livelihood Project, only nine farmers have been supplied with poultry, and 
only 15 other people have been trained in sericulture in an area where the combined population of rural villages numbers in the hundreds of thousands. Another AL program implemented by a neighbouring operation in collaboration with OICI targets only 30-40 farmers, awarding them farms which an officer at an NGO explained were located on "lands far away...[up to] ten miles".

\section{Marketing Issues}

In his analysis of local economic development in Africa, Helmsing (2003, p. 68) argues that "markets do not emerge spontaneously...[and that] the success of the innovating peasant...or small entrepreneur depends on the presence, effectiveness and efficiency of 'related and supporting' services". A similar view was echoed at the mining seminar in Kumasi by Professor Fobih, who noted that "whether it's snail rearing, how is the product of such livelihoods marketed?...The element of marketing is important".

Interviewees voiced two major concerns over the market potential of the products of the activities being promoted. First, is the provider - mainly, mining companies - aware of the local and national market potential of the products of the activities being promoted, as well as regional market disparities? A commodity such as snails, for example, despite being widely consumed, is not a preferred food in many of the localities where snail rearing is being promoted as an AL; but the impression given is that snails are widely consumed in all corners of Ghana. As argued in a recent article published in the Daily Graphic (Daily Graphic, 2003), “...with the passage of time,...snail meat has become the staple of almost every Ghanaian throughout the country...The meat is not only a delicacy but it is a component of what the rural Ghanaian will call a 'complete meal'”.

The market for snails, however, is greatest in the Eastern Region and Ashanti Region, where hundreds of farmers bring their supply to local markets as well as line the Accra-Kumasi road, hoping to attract passing travellers; thus, the snail-rearing projects implemented in places such as Bompata (Ashanti Region) and Obuasi (Ashanti Region) have been successful. Gold Fields has since incorporated snail rearing into its AL programs at its Damang and Tarkwa sites, as has BGL in its Sustainable Alternative Livelihood Project. The two main large-scale mine operators in the Western Region, these companies have, in all likelihood, pursued this initiative because of its well-publicized 
success in the neighbouring Ashanti Region; but there appears to be a significantly lower local demand for snail meat in these areas:

“...We are endowed with snails...I will take you to the back here, and I will count about 100 snails. I don't even eat them...Y You have to go into Kumasi...you will find about 1000 snails dodging and then moving around. We don't even eat them. Who's going to buy? Who is going to help me and take them into Kumasi?" [Sub-chief, Prestea/Bogoso]

Despite its undefined market potential, snail rearing projects continue to be implemented by mining companies throughout the Western Region.

Whilst there are regional market disparities for the outputs of certain AL activities, such as snails and perhaps grass-cutter, for other products, markets are, at best, significantly underdeveloped, requiring much more than the menial inputs of a mining company in order to be sustainable over the long term. For example, in the case of sericulture, despite claims made by one officer at BGL of a "[silk] market already being there, so the market is (in Ghana)", as previously explained, Ghana is neither a significant consumer of silk, nor is it a net exporter. In fact, apart from Ewe kente cloth, few Ghanaian products feature silk, which raises another question: how will the product reach the market? Ewes inhabit eastern Ghana in the Volta Region, hundreds of kilometres' distance from the Bogoso catchment areas of the Western Region where this silk is being produced. Are farmers expected to travel to Accra or Ho, the capital of the Volta Region, in order to access markets? Similarly, for vegetables and other cash crops, including oil palm, cassava and cocoa, unless transport services are provided so that groups selling their products can access wider markets, then additional barter-credit sharing schemes will surface, as now seen in galamsey camps in Noyem and Ntronang, which bring little external finance into the community.

Many of the alternatives being implemented are premised upon, as one mining company official put it, "giving the net, not the fish". Specifically, subsistence people are being provided inputs and encouraged to develop their own entrepreneurial ventures: "broilers" (roosters) and "layers" (hens) are being distributed to farmers for breeding; skills training in batik, soap-making and sericulture are being provided; and tilapia are being harvested and subsequently sold to peddlers and local "chop" bars for resale. This assumes, however, that there are existing markets where these skills can be applied and provisions utilized, which, at least in the case of silk, does not appear to be the case, for reasons already explained. It furthermore assumes that the impoverished people being targeted possess an in-depth knowledge of local markets and are capable of adjusting to market shocks. Most mining companies 
abandon these inexperienced and vulnerable groups after supplying them with inputs and hosting a series of meetings. Officers do little in the way of "promoting such development, particularly [with helping to identify] development paths that will involve and benefit the poor" (Dorward et al., 2003, p.323): few of the AL projects implemented in Ghana's mining regions are monitored and/or supported after their launch.

The decision of certain government departments and mining companies to promote activities in areas where there is limited market potential for products raises a second question: is it the intention of these organizations to enhance or, in fact, create, markets? For example, many "fish ponds", including those at the BGL demonstration farm, Resolute Amansie's decommissioned operation, Gold Fields' Damang site and Newmont's Kenyasi site, were constructed without determining the market potential for the tilapia they contain. The assumption in each case was that because fish is widely consumed in Ghana, increased supplies of tilapia would be welcomed by local groups, potentially creating a number of entrepreneurial activities; but the same assumption was made in Bolgatanga in the 1980s, when efforts were made to expand local tomato production. In addition to installing in the local factory inefficient machines, the government failed to take into account important tomato storage, production and marketing issues before the project's launch. It was not thought to put local schools on credit to purchase tomatoes, nor were restaurants and business cafeterias targeted: because people already had agreements in place with competing parties, the product proved difficult to sell. It appears that mining company officers have not considered any of these issues for tilapia, whether there are regional disparities for its demand, key issues related to marketability, and the prices consumers are willing to pay for supplies of fish.

Referring to Resolute Amansie's pond, one local government officer argued that "the catches and the cost of the catches are unattractive". Tilapia is highly expensive by African standards: in Ghana, one fish typically fetches between 70,000 and 90,000 cedis ${ }^{19}$ (depending upon weight) in a local "chop bar". Most companies are selling, or proposing to sell, their farmed tilapia in the range of 20,000-25,000 cedis, an expensive outlay in a country where GNI per capita is US $\$ 450^{20}$ per annum, and significantly less in rural areas. Company staff and government officials have failed to ascertain whether tilapia can be readily integrated into the country's rural markets ${ }^{21}$ where innumerable stalls sell "red fish", salmon, tuna, "kpala" and other inexpensive species as complements to local dishes such as banku, fufu and kenkeye. The durability and adaptability of tilapia certainly presents an 


\section{Discussion and Conclusions: "Rethinking" the Mining-Livelihoods Agenda in Ghana}

There is a sharp divide in opinion on how effective alternative livelihoods have been in practice in Ghana's mining communities. On the one hand, the parties championing AL policy, namely the mining companies, the government and the Chamber of Mines, purport that interventions have made a significant difference on the ground. On the other hand, local level actors, including representatives of target communities, claim that these parties are promoting few desirable incomeearning activities. Perhaps the most telling evidence in support of this view is the continued escalation of illegal mining, particularly within the areas where AL project work is taking place, a sign that programs are neither encompassing nor effective. This not only has important implications in Ghana but also in Mali, Tanzania, Burkina Faso and the many other African countries where the same mining companies are also operating.

One of the referees of this paper called for better contextualization of why extant AL-mining policy is so ineffective in Ghana, requesting for "some further reflection [on] whether ignorance/lack of knowledge (stemming from a top-down orientation) is the 'primary cause' for the failure of $\mathrm{AL}$ programs". The reviewer noted that an "alternative perspective - as argued persuasively by Ferguson [1999], for example - would be that these projects fail only in the narrow technical sense, but that they 'succeed' to the extent they de-politicise the thorny issue of re-allocating rights to land and resources towards mining firms". The problem, however, is that at least in the case of Ghana, these projects, championed by mining companies and the government as "community development initiatives", are by no means alleviating rural hardship and offsetting growing community dependency on illegal mining problems caused by "re-allocating rights to land and resources towards mining firms". A more pressing concern is why has this been the case, or more specifically, why do the Ghanaian authorities and private sector partners continue to promote ineffective and unpopular projects based largely upon their own ideas, rather than activities favoured by communities? Focusing on donors, Conyers and Mellors (2005, p. 84) attribute the continued promotion of impotent development interventions to 
insufficient understanding of policy environments in recipient countries, and the pressure for agencies to spend money for development purposes.

For ASM, it is not only a case of possessing insufficient information about the environments being targeted for support but also a lack of commitment to obtaining baseline data on recipient communities. Policy approaches emphasizing implementation of technical solutions with minimal commitment to analyzing rural populations have failed to facilitate improvements in the ASM sector, leading Hentschel et al. (2002, p. 38) to conclude that “[the industry's] problems cannot be solved by technically-oriented approaches alone". Jennings (2000, p. 17) reinforces this point, noting that "when assistance [for ASM]...is being developed and implemented, due consideration should be given to other issues — legal, financial, technical, cultural and political — that affect it". Whilst the launch of AL-mining projects and associated community development support programs may signify that a change in policy approach has occurred, technical staff, particularly mining engineering consultants, continue to be called upon to manage ASM support projects, including those which contain significant community and anthropological elements (Hilson et al., 2007b). This could help explain why the millions of dollars pledged toward supporting ASM in various capacities have failed to discourage illegal activity.

The general-ineffectiveness of extant AL-mining policy calls for a radical reorientation of approach, both for the benefit of Ghana's rural communities and mining settlements elsewhere in subSaharan Africa. It is recommended here that two significant changes be made. First, more desirable alternatives must be offered. If, indeed, it is the intention of Ghana's mining companies, through their AL programs, to "ensure the long-term sustainability of projects and mining communities, even after mining activities have ceased", 23 as officers at the Chamber of Mines proclaim, then there must be greater commitment to implementing projects which best reflect the realities on the ground. A large percentage $(74.8)^{24}$ of Ghana's population is literate; it cannot be assumed, therefore, that all of its people, including those residing in rural areas, aspire to become, or remain as, farmers. Comprehensive empirical analyses (e.g. Nyame 2002; Hilson and Potter 2005) reveal the breadth of skill now on hand in galamsey camps, and illustrate how diverse populations are in terms of background, ages and educational training. As already explained, OICI has been delegated significant responsibility when it comes to mining-AL decision-making in Ghana; in fact, it is safe to say that the organization has a monopoly on consultancy services in this area. Whilst the reason behind why 
Ghana's mining-AL programs are near-identical from site-to-site remains open to debate, there is evidence that consultants, many of whom, as mining engineers, are again, well out of their depth to conduct the requisite social and anthropological research, are truncating community analyses: as Conyers and Mellors (2005, p. 87-88) explain, "consultants...do anything, from developing policy and identifying areas of intervention to detailed project design and the actual management of development projects" (Conyers and Mellors, 2005, p. 87-88). The jury is still out on OICI but in the interim, there is merit in hiring additional hands to strengthen research and support teams. If mining companies and government departments are truly committed to improving quality of life in rural Ghana, then they should solicit the services of a range of people, including engineers, sociologists, economists and academics with demonstrable experience, to assist with the design and implementation of their AL projects.

Second, it is imperative that ASM populations themselves are also included in livelihood exercises. At present, the process of re-skilling and training is selective in a landscape which is highly complex, and where communities are undoubtedly interconnected. A line should not be drawn between so-called "catchment" settlements and galamsey communities because they are not mutually exclusive. By intentionally excluding the latter from these exercises, government and mining-company officials are undermining the very purpose of AL strategy. As previously explained, most mining companies include the communities that they have displaced in their AL exercises, raising yet another important question: should companies not be assisting the communities they have dislocated in the first place? Whilst the Chamber of Mines gives the impression that the livelihood initiatives instituted by Newmont, Gold Fields and AngloGold Ashanti have been implemented to discourage illegal mining, most, if not all, have been designed solely for the communities they are displacing.

At the institutional level, there appears to be an unrealistic expectation that all people will abandon their work as illegal miners if offered alternatives. Many, however, will not abandon galamsey activity in the short term - regardless of the alternative being provided - because of the income-earning potential; others have invested significant finances in equipment and operations, which they stand to lose should they walk away. Others still are committed to being artisanal miners over the long term. For example, many of the galamsey now working illegally on BGL's Prestea concession in the Western Region are former employees of the State Gold Mining Corporation, which, up until 1994, worked the same lands (Hilson and Yakovleva, 2007). The services of these skilled underground 
workers are in high demand in other galamsey camps in Noyem, Ntronang and Bolgatanga, where locals with minimal underground mining experience have solicited their services.

The likelihood of these groups of men abandoning this livelihood in favour of agricultural activities is low, which is why legalized ASM must also be offered as an alternative in government and corporate AL programs. Although a shortage of available land has prevented numerous artisanal mine operators from obtaining a concession through legal challenges, those who manage to secure a smallscale mining license certainly improve their chances of receiving training and consultation services from the government, and securing financial support from rural banks. Most of the lands which galamsey are currently working in Prestea, Noyem, Dunkwa and Ntronang are not being used by companies. With a legislative mechanism now in place to facilitate the transfer of mineral titles, the government must pressure companies to relinquish unused sections of concessions to galamsey leaders. Once this has taken place, quid pro-pro agreements could be readily forged, whereby a company provides environmental education and technical assistance to artisanal miners in exchange for extracted mineral product - typically, gold.

To summarize, in Ghana, government bodies and private sector partners have voiced their commitment to diversifying the economies of communities affected by mining. Funds have been pledged to further develop subsistence income-earning activities such as farming and livestock rearing, as well as develop other alternatives, such as sericulture. Although these exercises have received high praise from donor agencies and industry bodies, as this paper has illustrated, mining-AL policy in Ghana is largely driven from the top down, emphasizing the implementation of projects which affected groups are not necessarily calling for. If the government and the country's mining companies are genuinely committed to reducing illegal mining activity, they must rethink the AL exercise in its entirety.

\section{Acknowledgements}

The authors would like to thanks James Haselip and two anonymous reviewers for their constructive criticisms on a previous draft of this paper. The authors would also like to thank Mike Hilson for his assistance with the diagrams. Financial support for this research was provided by the Nuffield Foundation (SGS 32025), and the Research Support Fund, School of Environment and Development, 
University of Manchester. Needless to say, any errors this article may contain are the sole responsibility of the authors. 
${ }^{1}$ Throughout this paper, "artisanal mining" and "small-scale mining" are used interchangeably.

${ }^{2}$ Consensus on these definitions was reached at DfID's Natural Resources Adviser's Conference on Sustainable Livelihoods.

${ }^{3}$ As Hilson and Nyame (2006) explain, by law, of the 3 percent royalty payment mining companies are required to pay ( 3 percent of the gross value of minerals extracted), 80 percent belongs to the central government, with the remaining 20 percent deposited into the Mineral Development Fund. Half of these monies are given to mining agencies and the other half to the Office of the Administrator of Stool Lands, which retains 10 percent, and allocates the remaining 90 percent to the following authorities for community development purposes: 1) district assemblies (55 percent); 2) traditional authorities (20 percent); and 3) the stools of mining areas (25 percent).

${ }^{4}$ For example, in Noyem there are people working as diggers, ore washers, haulers, security officers and drivers. There are also regular "taxi runs" from mining camps to the nearby towns of Nkawkaw and New Abirem, as well as thousands of women at work in local markets, selling everything from ore sacks, to replacement machinery parts, to marijuana and local liquors.

${ }^{5}$ As explained by Hinton (2005), "lured by the possibility of "hitting it rich"” (CASM, 2005, p. 19), an increasing number of people are moving from townships and urban areas to rural regions to engage in artisanal mining: in effect, the sector is fuelling urban-rural migration.

${ }^{6}$ The grass-cutter (Thryonomys swinderianus) is a rodent of the suborder Hystricomorpha, whose natural habitat is the tall grassland of the Guinea Savannah.

${ }^{7}$ It may appear that prospecting and exploration companies do not hold on to parcels of land for significant periods of time. But combined, the reconnaissance and exploration phase can span 10-15 years (see www.ghanamining.org). A reconnaissance license permits the holder to search for minerals using geochemical and photo-geological means. This license can be renewed for up to one year, although the Minister can intervene to grant a company a longer lease. A prospecting (exploration) license grants the holder the right to conduct geological/geophysical investigations within a designated area not exceeding $150 \mathrm{~km}^{2}$ for a period of three years. The license can be renewed for up to two terms (of up to two years each). A mining lease gives the holder the right to mine and process minerals within an area not exceeding $50 \mathrm{~km}^{2}$ in the case of gold for a period of 30 years, subject to renewal for another 30-year term.

${ }^{8}$ Data obtained from www.ghanadistricts.com

${ }^{9}$ Data obtained from www.ghanadistricts.com

${ }^{10}$ Data extracted from

http://www.ghanadistricts.com/districts/?news\&r=4\&_=68\&PHPSESSID $=b 639 \mathrm{c} 72 \mathrm{f} 8 \mathrm{e} 9 \mathrm{a} 2062562 \mathrm{df03}$ 96e83da40 (accessed 10/05/07) and the Ghana Statistical Service (Ghana Statistical Service, 2002).

${ }^{11}$ Data extracted from http://www.ghanadistricts.com/districts/?news\&r=4\&_=68\&PHPSESSID $=b 639 \mathrm{c} 72 \mathrm{f} 8 \mathrm{e} 9 \mathrm{a} 2062562 \mathrm{df03}$ $\underline{9683 \mathrm{da} 40}$ (accessed 11/05/07)

12

http://www.ghanadistricts.com/news/?read=4553\&PHPSESSID=bae13857fd2bc057a7ae001bfba14b44 (accessed 11/05/07)

${ }^{13}$ In total, 10 mining company officials, 15 galamsey heads/elders, eight government officers and employees from five NGOs were interviewed.

${ }^{14} \mathrm{OICI}$ is currently managing the following three mining-livelihoods projects in Ghana: for Newmont Ghana, the Livelihood Enhancement and Community Empowerment Program; for AngloGold Ashanti, 
the Ghana AngloGold Ashanti Hand-to-Hand Community Development Program; and for Gold Fields Ghana, the Sustainable Community Empowerment and Economic Development Program.

${ }^{15}$ A recent incident in Burkina Faso, however, does suggest that OICI is at least partly responsible. Searching for an outfit to provide advice on how to re-skill thousands of artisanal miners at its Essakane site in Northern Burkina, Gold Fields called upon OICI to deliver a presentation. The powerpoint presentation given, however, had a "Newmont" logo on each slide: the same presentation had clearly been delivered to Newmont in Ghana at an earlier date. Essentially, the same solutions were being prescribed for two different environments.

16 “Wassa West farmers to begin Silk Farming”, Accra Daily Mail 20/04/04.

${ }^{17}$ Officers at the Ghana Chamber of Mines continue to praise BGL's Alternative Livelihood Project. When asked about the effectiveness of the AL projects implemented countrywide, one senior officer responded: "I would be surprised if none are not working".

${ }^{18}$ Families have been promised the following incomes: US\$624 in the second year; US\$1248 in the third year; US\$1796 in the fourth year; and US\$1952 in the fifth year. These sums do not take into account inflation.

${ }^{19}$ There are approximately 9000 cedis in 1 US dollar (conversion rate as of September 2006).

${ }^{20}$ See http://www.doingbusiness.org/ExploreEconomies/Default.aspx?economyid=76 (accessed 08/09/06).

${ }^{21}$ The decision to farm tilapia is something which mining company officials have decided on their own, without any significant market analysis. In the case of BGL, the company itself coordinated a tilapia market study in Prestea and Bogoso, the results of which are unavailable to the public. The exercise, however, was likely far from comprehensive: the company has very poor relations with surrounding communities.

${ }^{22}$ This is not to say that a new market cannot be created. This discussion is merely questioning the commitment of companies to expand or re-establish a rural market: there is simply not enough inertia or more importantly, money, being put into the projects. There have, however, been several success stories elsewhere - in large part because a company has committed itself to establishing a market. At Yanococha in Peru, for example, the mine operator - Newmont - commissioned a seamstress to provide uniforms for the company. She then hired 300 seamstresses because by "piggy-backing" on the mine, she has managed to secure a number of customer orders in Lima. Newmont was also the first customer of a local metal fabricator, who has since managed to build up a significant customer base in the region.

${ }^{23}$ Excerpted from the article "Chamber of Mines: Supporting Mining in Africa", Mining Review Africa, Issue 6, 2004. http://www.miningreview.com/archive/mra_6_2004/36_1.php (accessed 21/09/06).

${ }^{24}$ See http://www.indexmundi.com/ghana/literacy.html (accessed 22/09/06). 


\section{References}

Akabzaa, T., Darimani, A. (2001) Impact of Mining Sector Investment in Ghana: A Study of the Tarkwa Mining Region (Washington DC: SAPRIN).

Andrew J.S. (2003) Potential application of mediation to land use conflicts in small-scale mining, Journal of Cleaner Production, 11(2), pp. 117-130.

Aryee, B.N.A. (2001) Ghana's mining sector: its contribution to the national economy, Resources Policy, 27(2), pp. 61-75.

Ashley, C. and Carney, D. (1999) Sustainable Livelihoods: Lessons from Early Experience (London: UK-Department for International Development)

Aubynn, A. (1997) Liberalism and Economic Adjustment in Resource Frontiers: Land-Based Resource Alienation and Local Responses, A Reflection from Western Ghana, Working Paper 9/97, IDS, University of Helsinki, Finland.

Aubynn, A. (2006) 'Live and let live': The relationship between artisanal/small-scale and large-scale miners at Abosso Goldfields, Ghana, in: G.M. Hilson (ed) Small-Scale Mining, Rural Subsistence and Poverty in West Africa (Rugby: PracticalAction), pp. 221-234.

Auty, R. (1994) Industrial reform in 6 large newly industrializing countries - the Resource Curse Thesis, World Development, 22(1), pp. 11-26.

Banchirigah, S.M. (2006) How have reforms fuelled the expansion of artisanal mining? Evidence from Sub-Saharan Africa, Resources Policy, 31(3), pp. 165-171.

Bank of Ghana. (2003) Report on the Mining Sector (Accra: Bank of Ghana).

Barry, M. ed. (1996) Regularizing Informal Mining: A Summary of the Proceedings of the International Roundtable on Artisanal Mining. Industry and Energy Department Occasional Paper No. 6, World Bank Washington DC.

Barrett, C.B., Reardon, T. and Webb, P. (2001) Nonfarm income diversification and household livelihood strategies in rural Africa: concepts, dynamics, and policy implications, Food Policy, 26(4), pp. 315-331.

Bridge, G. (2004) Mapping the Bonanza: Geographies of Mining Investment in an Era of Neoliberal Reform, The Professional Geographer, 56(3), pp. 406-421.

Bryceson, D.F. (2002a) Multiplex livelihoods in rural Africa: recasting the terms and conditions of gainful employment, Journal of Modern African Studies, 40(1), pp. 1-28.

Bryceson, D.F. (2002b) The scramble in Africa: Reorienting rural livelihoods, World Development, 30(5), pp. 725-739.

Bury, J. (2004) Livelihoods in transition: transnational gold mining operations and local change in Cajamarca, Peru, Geographical Journal, 170(1), pp. 78-91.

Campbell, B. (2003) Factoring in Governance is not enough: Mining Codes in Africa, Policy Reform and Corporate Responsibility, Minerals and Energy, 18(3), pp. 2-13

Canagarajah, S. and Portner, C.C. (2003) Evolution of Poverty and Welfare in Ghana in the 1990s: Achievements and Challenges, Africa Region Working Paper Series No. 61, World Bank, Washington DC.

Carnegie, J. (2002) Sustainable Livelihoods and Artisanal \& Small-Scale Mining, in: Identifying Best Practices and Building the Sustainable Livelihoods of Communities, UNECA, Ethiopia, pp. 63-66,. 
Carney, D. (1998) Implementing the Sustainable Rural Livelihoods Approach, in: Carney, D. (ed), Sustainable Rural Livelihoods: What Contribution Can We Make? UK-Department for International Development, UK, pp. 3-23.

Carson, M., Cottrell, S., Dickman, J., Gummerson, E., Lee, T., Miao, Y., Teranishi, N., Tully, C. and Uregian, C. )2005). Managing Mineral Resources through Public-Private Partnerships: Mitigating Conflict in Ghanaian Gold Mining. Working Paper WWS591c, Woodrow Wilson School of Public and International Affairs, Princeton University, New Jersey.

Chachage, C.S.L. (1995) The Meek Shall Inherit the Earth but Not the Mining Rights: The Mining Industry and Accumulation in Tanzania, in: P. Gibbon (ed), Liberalised Development in Tanzania, Nordiska Afrikainstitutet, Uppsala, pp. 37-108.

Chambers, R. and Conway, G. (1991) Sustainable Rural Livelihoods: Practical Concepts for the 21st Century, IDS Working Paper 296, Institute for Development Studies, Sussex.

Communities and Small-Scale Mining (CASM). (2005) The Millennium Development Goals and Small-Scale Mining: A Conference For Forging Partnerships For Action (Washington DC: The World Bank).

Coyners, D. and Mellors, R. (2005) Aid Ineffectiveness in Sub-Saharan Africa: The Problem of Donor Capacity, IDS Bulletin, 36(3), pp. 83-89.

Daily Graphic. (2003) Snails, another gem in export trade. 18 February 2003 http://www.ghanaweb.com/GhanaHomePage/economy/artikel.php?ID=32981 (accessed 22/0906).

Dorward, A., Poole, N., Morrison, J., Kydd, J. and Urey. I. (2003) Markets, Institutions and Technology: Missing Links in Livelihoods Analysis, Development Policy Review, 21 (3), pp. 319-332.

Dreschler, B. (2001) Small-scale Mining and Sustainable Development within the SADC Region (London: International Institute for Environment and Development).

Ellis, F. (1998) Household Strategies and Rural Livelihood Diversification. Journal of Development Studies, 35(1), pp. 1-38.

Ellis, F. (2000) Rural Livelihoods and Diversity in Developing Countries (Oxford: Oxford University Press).

Ferguson, J. (1999) Expectations of modernity: myths and meanings of urban life on the Zambian Copperbelt (Berkeley: University of California Press).

Ghana Chamber of Mines. (2006) Ghana Chamber of Mines Factoid 2006. Ghana Chamber of Mines http://ghanachamberofmines.org/internet/index.php (accessed 31/01/07).

Havnevik, K., Negash, T. and Beyene, A. (2006) Introduction to Rural Livelihood and Governance Issues, in: Havnevik et al. (eds) Of Global Concern - Rural Livelihoods Dynamics and Natural Resource Governance, SidaStudies, Sweden, pp. 11-25.

Helmsing, A.H.J. (2003) Local Economic Development: New Generations of Actors, Policies and Instruments for Africa, Public Administration and Development, 23, pp. 67-76.

Hentschel, T., Nruschka, F. and Priester, F. (2002) Global Report on Artisanal and Small-Scale Mining. Working Paper 70, Mining, Minerals and Sustainable Development (MMSD) Project, London.

Hilson, G. (2004) Structural Adjustment in Ghana: Assessing the Impacts of Mining Sector Reform, Africa Today, 51(2), pp. 53-77. 
Hilson, G. and Maponga, O. (2004) How has a shortage of census and geological data inhibited the regularization of artisanal and small-scale mining? Natural Resources Forum, 28(1), pp. 22-33.

Hilson, G. and Potter, C. (2005) Structural adjustment and subsistence industry: artisanal gold mining in Ghana, Development and Change, 36(1), pp. 103-131.

Hilson, G. and Nyame, F. (2006) Gold Mining in Ghana's Forest Reserves: A Report on the Current Debate, Area, 38(2), pp. 175-185.

Hilson, G. and Yakovleva, N. (2007) Strained relations: a critical analysis of the perspectives on the mining conflict in Prestea, Ghana, Political Geography, 26(1), pp. 98-119.

Hilson, G., Yakovleva, N. and Banchirigah, S.M. (2007a) 'To move or not to move': reflections on the resettlement of artisanal miners in the Western Region of Ghana, African Affairs (in press).

Hilson, G., Hilson, C.J. and Pardie, S. (2007b) Improving Awareness of Mercury Pollution in SmallScale Gold Mining Communities: Challenges and Ways Forward in Rural Ghana, Environmental Research, 103(2), pp. 275-287.

Hinton, J. (2005) Communities and Small-Scale Mining: An Integrated Review for Development Planning (Washington DC: The World Bank).

Hinton, J.J., Veiga, M.M. and Veiga, A.T.C. (2003) Clean artisanal gold mining: a utopian approach? Journal of Cleaner Production, 11(2), pp. 100-115.

International Labour Organization (ILO). (1999) Social and labour issues in small-scale mines (Geneva: ILO).

Jennings, N.S. (2000) Small-scale mining: a sector in need of support, Mining Environmental Management, 8(1), pp. 17-18.

Kitula, A.G.N. (2006) The environmental and socio-economic impacts of mining on local livelihoods in Tanzania: A case study of Geita District, Journal of Cleaner Production, 14, pp. 405-414.

Labonne, B. and Gilman, J. (1999) Towards Building Sustainable Livelihoods in the Artisanal Mining Communities, paper presented at the Tripartite Meeting on Social and Labour Issues in Small-scale Mines, ILO, Geneva.

Maconachie, R. and Binns, T. (2007) 'Farming miners' or 'mining farmers'?: Diamond mining and rural development in post-conflict Sierra Leone, Journal of Rural Studies, 23(3), pp. 367-380.

McCusker, B. and Carr, E.R. (2006) The co-production of livelihoods and land use change: Case studies from South Africa and Ghana, Geoforum, 37, pp. 790-804.

MIME Consult. (2002) Poverty Eradication and Sustainable Livelihoods: Focusing on Artisanal Mining Communities. Report Prepared for the UNDP, MIME Consult, Accra.

Mondlane, S. and Shoko, D.S.M. (2003) The Socio-Economic and Environmental Impacts of Artisanal and Small-Scale Mining in Mozambique, in: G.M. Hilson (ed), The Socio-Economic Impacts of Artisanal and Small-Scale Mining in Developing Countries (The Netherlands: A.A. Balkema), pp. 265280.

Morgan, P.G. (2002) Mineral title management - the key to attracting foreign mining investment in developing countries? Transactions of the Institution of Mining and Metallurgy, 111, pp. B165-B170.

Norton, A. and Foster, M. (2001) The potential of using sustainable livelihoods approaches in poverty reduction strategy papers, Working Paper 148, Overseas Development Institute, London. 
Nyame, F.K. (2002) Mining Sector Development and Environmental Project: Local Economic Development (LED) Projects in Mining Communities in Ghana (Phase II), Report Prepared for the Minerals Commission, Accra.

Opportunities Industrialization Centers International (OICI). (2006) Sustainable Livelihoods \& Community Development. Opportunities Industrialization Centers International (OICI), Philadelphia.

Pegg, S. (2003) Poverty Reduction or Poverty Exacerbation? World Bank Group Support for Extractive Industries in Africa. Oxfam America, USA.

Pegg, S. (2006) Mining and poverty reduction: Transforming rhetoric into reality, Journal of Cleaner Production, 14(3-4): pp. 376-387.

Ruffini, A. (2006) The revival of Zambia's copper mining sector - Rising copper prices renew interest in the Copperbelt, Engineering and Mining Journal, 207(2), pp. 39-43.

Shankland, A. (1998) Analysing Policy for Sustainable Livelihoods. Research Report 49, International Development Institute, UK.

Sievanen L., Crawford, B., Pollnac, R. and Milne, N. (2005) Weeding through assumptions of livelihood approaches in ICM: Seaweed farming in the Philippines and Indonesia, Ocean and Coastal Management, 48(3-6), pp. 297-313.

Toner, A. (2003) Exploring Sustainable Livelihoods Approaches in Relation to Two Interventions in Tanzania, Journal of International Development, 15, pp. 771-781.

Twyman, C. and Slater, R. (2005) Hidden livelihoods? Natural resource-dependent livelihoods and Urban Development Policy, Progress in Development Studies, 5(1), pp. 1-15.

United Nations (UN). (1996) Recent Developments in Small-Scale Mining. Economic and Social Council (New York: United Nations).

Whitehead, A. (2004) Persistent Poverty in North East Ghana. BASIS Collaborative Research Support Program, Department of Agricultural and Applied Economics, University of WisconsinMadison, USA.

World Bank. (2004) Mining Regional Strategies: Africa. http://www.worldbank.org/ogmc/wbminingafrica.htm (accessed 10/10/04).

Yaro, J.A. (2006) Is deagrarianisation real? A study of livelihood activities in northern Ghana, Journal of Modern African Studies, 44(1), pp. 125-156. 